\title{
Non-Institutional Review Board Independent Ethics Committee Approved Submission Document
}

National Cancer Institute

\section{Source}

National Cancer Institute. Non-Institutional Review Board Independent Ethics Committee

Approved Submission Document. NCI Thesaurus. Code C115716.

Records that describe the changes and/or updates made to a clinical trial, and are submitted for approval to a committee other than the Institutional Review Board (IRB)/Independent Ethics Committee (IEC). 